\title{
Absence of PRKARIA Loss of Heterozygosity in Laser-Captured Microdissected Pigmented Nodular Adrenocortical Tissue from a Patient with Carney Complex Caused by the Novel Nonsense Mutation p.Y21X
}

\begin{abstract}
Objective: Primary pigmented nodular adrenocortical disease (PPNAD) is the main endocrine manifestation of Carney complex, a multiple neoplasia syndrome caused by PRKAR1A gene mutations. The presence of PRKAR1A loss of heterozygosity $(\mathrm{LOH})$ in adrenocortical tumorigenesis remains controversial. The aim of the present study is to investigate the presence of PRKAR1A $\mathrm{LOH}$ in adrenocortical cells in a patient with Carney complex. Methods: The $\mathrm{LOH}$ was investigated using a PRKAR1A informative intragenic marker by GeneScan software analysis in DNA obtained from laser-captured microdissected cells of several adrenal nodules. Patients: A young adult male patient with Carney complex and his family were studied. Results: A novel heterozygous mutation ( $p$. Y21X) was identified at PRKAR1A in blood DNA of the male proband and his relatives. No PRKAR1A LOH was evidenced in the laser-captured microdissected cells from PPNAD tissue by different methodologies. Conclusion: We identified a new PRKAR1A nonsense mutation and in addition we did not evidence PRKAR1A LOH in laser-captured nodules cells, suggesting that adrenocortical tumorigenesis in PPNAD may occurs apart from the second hit. (Arq Bras Endocrinol Metab 2008; 52/8:1257-1263)
\end{abstract}

Keywords: PRKAR1A; PPNAD; LOH; Laser-captured microdissection

\section{RESUMO}

Ausência da Perda de Heterozigose do PRKAR1A em Células Capturadas por Microdissecção a Laser de Tecido de Nódulo Pigmentoso Adrenocortical de um Paciente com Complexo de Carney Causado por uma Nova Mutação Nonsense.

Objetivo: A doença adrenocortical nodular pigmentosa primária (PPNAD) é uma das manifestações do complexo de Carney, uma neoplasia endócrina múltipla causada por mutações no PRKAR1A. A perda de heterozigose (LOH) do PRKAR1A na tumorigenese adrenal permanece controversa dada à possibilidade de contaminação com o tecido normal. Nosso objetivo foi investigar a presença de LOH no PRKAR1A a partir de células do nódulo adrenal de um paciente com complexo de Carney. Métodos: A pesquisa da $\mathrm{LOH}$ do $P R K A R 1 A$ foi realizada através do estudo de um marcador intragênico em DNA de células do nódulo adrenal microdissecadas a laser, evitando contaminação com o tecido normal. Pacientes: Um paciente com PPNAD e cinco familiares foram estudados. Resultados: A nova mutação (p. Y21X) foi identificada no PRKAR1A sem evidência de LOH no tecido adrenal. Conclusão: Identificamos uma nova mutação no PRKAR1A e não evidenciamos $\mathrm{LOH}$ nas células dos nódulos adrenocorticais, sugerindo que a PPNAD possa ocorrer na ausência de um segundo evento molecular. (Arq Bras Endocrinol Metab 2008; 52/8:1257-1263)

Descritores: PRKAR1A; PPNAD; LOH; Microdissecção; Captura a laser clinical case report

\author{
Madson Q. Almeida \\ LUCIANA PINTO BRITO \\ SORAHIA DOMENICE \\ Marcia Helena Soares Costa \\ EMILIA Modolo PINTO \\ Cynthia A. Toledo Osório \\ ana Claudia latronico \\ BERENICE B. MENDONCA \\ Maria Candida B. V. Fragoso
}

Unidade de Endocrinologia do Desenvolvimento e Laboratório de Hormônios e Genética Molecular LIM-42, Hospital das Clínicas da Faculdade de Medicina da Universidade de São Paulo (MQA, LPB, SD, MHSC, EMP, ACL, BBM, MCBVF);

Departamento de Anatomia Patológica do Hospital do Câncer de São Paulo (CATO), São Paulo, SP, Brasil.

Received in 25/8/2008

Accepetd in 23/9/2008 


\section{INTRODUCTION}

arney complex is a multiple endocrine neoplasia syndrome characterized by spotty skin pigmentation, cardiac and extracardiac myxomas, schwannomas, and endocrine tumours (1). Primary pigmented nodular adrenocortical disease (PPNAD), a rare cause of ACTHindependent Cushing syndrome, is the main endocrine manifestation of Carney complex $(1,2)$. Mutations of the gene encoding protein kinase A regulatory subunit $1 \alpha(P R K A R I A)$ represent the molecular aetiology of approximately $41 \%$ of the kindreds affected by Carney complex (3-6). Additionally, genetic linkage analysis has identified other genetic loci on chromosome $2 \mathrm{p}$ in families with Carney complex $(7,8)$.

PRKAR $I A$ appears to function as a classic tumour suppressor gene(3). To date, PRKARIA loss of heterozygosity $(\mathrm{LOH})$ studies were reported in 16 lesions caused by Carney complex (3,4,9-12). In several of these cases, tumours displayed $17 \mathrm{q} 22-24 \mathrm{LOH}$ or allelic loss, particularly in GH-producing pituitary adenomas, thyroid and testicular tumours $(3,10)$. In contrast, subsequent studies demonstrated that cardiac and other myxomas exhibited PRKARIA LOH inconsistently $(4,9)$. In addition, retention of heterozygosity was also demonstrated by direct sequencing of PRKARIA in adrenocortical tissue from three patients with isolated PPNAD (11). LOH analysis can often be misdiagnosing due to significant contamination with normal cells that surround tumours. The laser-captured microdissection is currently considered the best way to overcome surrounding tissue admix- ture $(13,14)$. Very recently, Mavrakis and cols. (15) demonstrated the presence of $\mathrm{LOH}$ exclusively in nodular areas of laser-captured microdissected PPNAD tissue from a patient with Carney complex. However, PRKARIA LOH was based only on the segregation of a single polymorphic marker $(G A$ TAlE12) located $3 \mathrm{cM}$ upstream the PRKARIA gene, which makes this finding very inconsistent (15). Therefore, additional LOH studies in laser-captured microdissected adrenal nodules of PPNAD tissue would be relevant to clarify the controversial aspects involving PRKARIA LOH occurrence. Herein, we carried out an $\mathrm{LOH}$ analysis for an intragenic PRKA$R l A$ marker in laser-captured microdissected cells of PPNAD tissue from a patient with familial Carney complex, caused by a novel PRKARIA mutation.

\section{SUBJECTS AND METHODS}

The protocol was approved by the Ethical Committee of Hospital das Clinicas, School of Medicine of the University of São Paulo. Informed and written consent was obtained from the proband and his relatives.

A 17-year-old male patient was referred for endocrine evaluation of suspected Cushing's syndrome. He presented central obesity (BMI $32 \mathrm{~kg} / \mathrm{m}^{2}$ ), facial plethora, abdominal purple striae, spotty skin pigmentation (lentiginoses) and high blood pressure (160/100 $\mathrm{mmHg}$ ). Hormonal investigation revealed ACTH-independent Cushing syndrome (Table 1). Magnetic resonance imaging (MRI) revealed multiple left and right adrenocortical micronodules (Figure 1A). Testicular,

Table 1. Clinical, hormonal, and imaging findings of a family with Carney complex caused by the p. Y21X mutation of the PRKARIA.

\begin{tabular}{|c|c|c|c|c|}
\hline & Proband & Father & Sister 1 & Sister 2 \\
\hline Age at the initial evaluation (yr) & 17 & 52 & 15 & 13 \\
\hline Lentiginoses & Yes & Yes & Yes & Yes \\
\hline Overt Cushing syndrome & Yes & No & No & No \\
\hline $\begin{array}{l}8 \text { am serum cortisol* }^{*} \\
\text { (normal levels }<1.8 \mu \mathrm{g} / \mathrm{dL} \text { ) }\end{array}$ & 29 & 2.0 & 5.1 & 4.6 \\
\hline ACTH (normal levels: $18-60$ pg/mL) & $<18$ & $<18$ & $<18$ & $<18$ \\
\hline $\begin{array}{l}\text { 24-h urinary non-extracted cortisol } \\
\text { (normal levels }<300 \mu \mathrm{g} / 24 \mathrm{~h} \text { ) }\end{array}$ & 1736 & 345 & 258 & 215 \\
\hline Adrenal CT scan & micronodules & normal & normal & normal \\
\hline Low bone mass & Yes & $\mathrm{NA}^{\pi}$ & NA $A^{\pi}$ & Yes \\
\hline
\end{tabular}


A

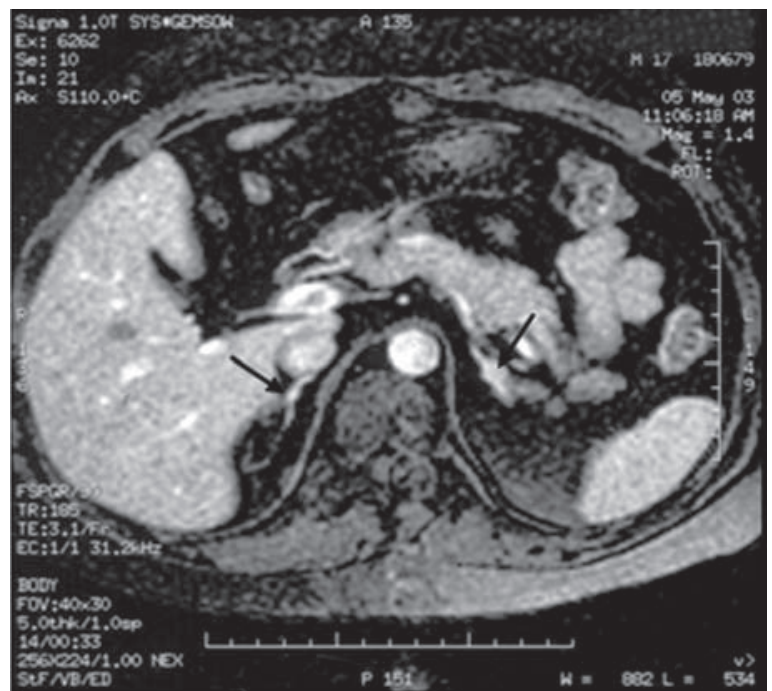

C
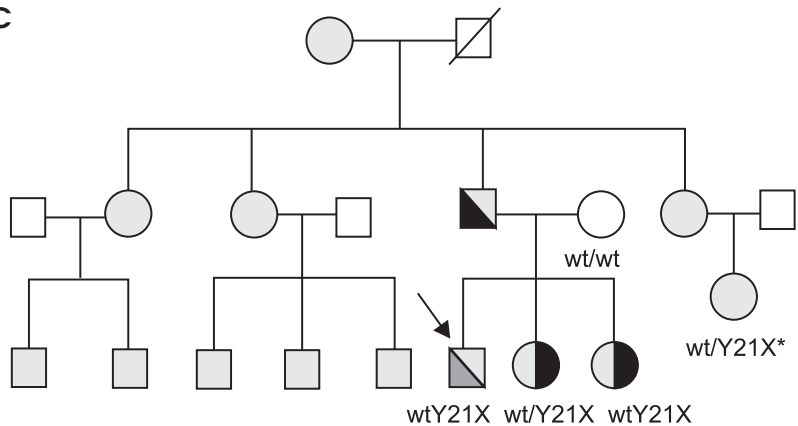

Lentiginoses $w t Y 21 X w t / Y 21 X$ wtY21X

CS Subclinical CS

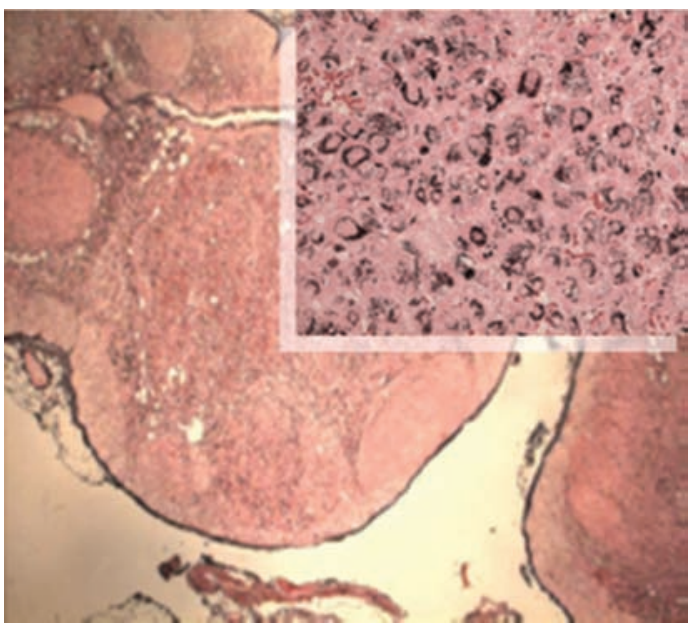

D

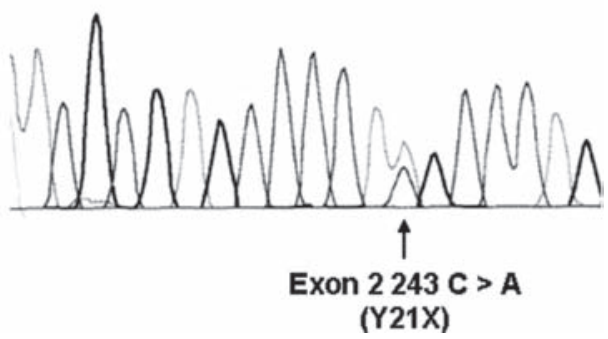

Figure 1. (A) Adrenal MRI revealed small bilateral adrenal nodules (arrows). (B) Intracellular lipofuscin pigments revealed by Fontana-Masson staining. (C) Pedigree of the family with Carney complex. *Short stature and a past history of precocious puberty, but without hormonal investigation. (D) Nonsense PRKARIA mutation in exon 2 at codon 21 (TAC $\rightarrow$ TAA) encoding a substitution of a tyrosine by a stop codon (p. Y21X).

thyroid and cardiac ultrasound and pituitary MRI were normal. Serum concentrations of $\mathrm{GH}$, prolactin and IGFI were within the normal range.

He underwent laparoscopic bilateral adrenalectomy. Both adrenal glands had an overall normal size and weight and featured multiple small yellow to dark brown nodules. Microscopically, both adrenal glands showed several multiple pigmented nodules (1-5 mm) surrounded by apparently normal adjacent adrenal cortex; Fontana-Masson staining revealed intracellular lipofuscin pigments (Figure 1B).

Four first-degree relatives were evaluated through history and physical examination. Hormonal and imaging screenings for diagnosis of hypercortisolism were performed in his father and two younger sisters without Cushing's syndrome features. Bone densitometry was also performed in the male proband and his youngest sister.

\section{Hormonal assays}

ACTH was measured by an immunoradiometric kit (ELSA-ACTH, CIS bio international) with intra- and interassay CVs $<14 \%$ and $<20 \%$, respectively, which are appropriate for an ACTH range of $18-2,420 \mathrm{pg} / \mathrm{mL}$. Serum and urinary cortisol were measured by fluoroimmunoassay in an AutoDelfia System (Wallac Oy, Turku, Finland), with intra- and interassay coefficients of variation $(\mathrm{CVs})<10 \%$ and $<12 \%$, respectively.

\section{DNA analysis}

Genomic DNA was extracted from peripheral blood leukocytes and frozen tumour tissue of the proband using standard procedures. Molecular studies were also performed in six relatives (his parents, two sisters, one paternal aunt and a female cousin). The 12 exons and the flanking intronic sequences of the PRKARIA gene 
were amplified using the previously described primers and conditions (5). The PCR products were pretreated with an enzymatic combination of exonuclease I and shrimp alkaline phosphatase (United 7 States Biochemical Corp., Cleveland, $\mathrm{OH}$ ) and directly sequenced using the BigDyeTM terminator cycle sequencing ready reaction kit (PE Applied Biosystems, Foster City, CA) in an ABI PRISM 310 automatic sequencer (Perkin Elmer Cetus).

\section{Laser-captured microdissection and DNA extraction of PPNAD cells}

Adrenal frozen tissue was cut into $7-\mu \mathrm{m}$ sections and subsequently hydrated in $70 \%$ ethanol solution for 30 seconds, followed by staining with $100 \mu \mathrm{l}$ of Toluidine blue for 20 seconds after rinsing with distilled water. The sections were dehydrated in graded $75 \%, 95 \%$ and $100 \%$ ethanol for 30 seconds each and dipped in xylene for 5 minutes. After air-drying, laser-captured microdissection was performed in selected regions onto a thermoplastic film mounted on optically transparent LCM cap (CapSure Macro LCM Cap, Arcturus). A Pix Cell II Laser capture instrument (Arcturus, Mountain View, CA) was used to microdissect several PPNAD nodules $(>10,000$ cells) by focal melting of the membrane through laser activation. A cap with captured cells was inserted into a $0.5 \mathrm{ml}$ microcentrifuge tube and DNA extraction was performed according to Pico pure DNA Extraction Kit (Arcturus, Mountain View, CA). The exon 2 of PRKARIA was amplified and sequenced as previously described (5).

\section{PRKAR1A LOH analysis}

Primer for the dinucleotide repeats $(\mathrm{CA})_{\mathrm{n}}$ intragenic marker for PRKARIA gene have been published elsewhere (5). The forward primer was labelled with fluorescent dye (FAM). Genomic DNA (100 ng), extracted from blood leukocytes, PPNAD tissue and laser-captured microdissected tumour cells was then added to a 50-ul reaction mixture of $1 x$ PCR buffer $(50 \mathrm{mM} \mathrm{KCl}, 1.5 \mathrm{mM} \mathrm{MgCl}$, and $10 \mathrm{mM}$ Tris $/ \mathrm{HCl}$, $\mathrm{pH} 9.0), 200 \mu \mathrm{M}$ of each dNTP, $20 \mathrm{pmol}$ of each primer, and 2.5 U Taq DNA polymerase (Amersham Pharmacia, Uppsala, Sweden). The PCR mixture was denatured for $5 \mathrm{~min}$ at $94^{\circ} \mathrm{C}$ and cycled 35 times $(94$ ${ }^{\circ} \mathrm{C}$ for $30 \mathrm{sec}, 50-62{ }^{\circ} \mathrm{C}$ for $30 \mathrm{sec}$, and $72{ }^{\circ} \mathrm{C}$ for 30 sec), followed by a 30 -min extension at $72^{\circ} \mathrm{C}$. Internal size standard TAMRA 350 (Applied Biosystems,
Foster City, CA) was added to $2 \mu \mathrm{l}$ of PCR products and $24 \mu \mathrm{l}$ of formamide, and those were submitted to capillary electrophoresis in an automatic sequencer (ABI Prism 310 genetic analyser) followed by GeneScan fragment analysis (Applied Biosystems, Foster City, CA). We applied a criterion for $\mathrm{LOH}$ scoring using the ratio of the heights of the allele peaks obtained from the tumour and the blood samples. An allelic imbalance ratio less than 0.5 or more than 2.0 was defined as $\mathrm{LOH}(16,17)$.

\section{RESULTS}

Automated sequencing revealed a novel germline PRKARIA mutation in exon 2 at codon 21 (TAC $\rightarrow$ TAA), encoding a substitution of a tyrosine by a stop codon (p. Y21X), in heterozygous state in the proband as well as in his father, two younger sisters, one paternal aunt and a female cousin (Figure IC and 1D). All of them exhibited lentiginoses. Even though only the proband had overt Cushing syndrome, his father and the two sisters who carried the same mutation had evidence of hormonal abnormalities (Table 1) (18). Although the serum cortisol levels after overnight $1 \mathrm{mg}$ dexamethasone test were borderline, the suppressed ACTH levels, as well as the slightly elevated 24-h urinary non-extracted cortisol indicated the diagnosis of subclinical cortisol hypersecretion in the father. Similarly, both sisters also had suppressed ACTH levels and non-suppressed serum cortisol levels after the overnight low-dose dexamethasone suppression test. The male proband and his youngest sister also presented low bone mass ( $\mathrm{Z}$ score $<-2 \mathrm{SD})$.

The p. Y21X mutation was also identified in heterozygous state in PPNAD tissue from the proband. The sequencing analysis of the entire coding region of the PRKARIA ruled out the possibility of a somatic defect in compound heterozygosity with the p. Y21X mutation in this patient. Two distinct alleles of the intragenic marker for PRKARIA were identified in DNA from blood lymphocytes as well as in adrenocortical tumour tissue, demonstrating no allelic loss involving PRKARIA gene in PPNAD tissue. Absence of PRKA$R I A \mathrm{LOH}$ for the p. Y2IX mutation as well as for the dinucleotide repeat $(\mathrm{CA})_{\mathrm{n}}$ intragenic marker were confirmed in DNA obtained from PPNAD cells after lasercaptured microdissection, indicating that wild-type (WT) PRKARIA allele retention is not a consequence of normal tissue contamination (Figure 2). 


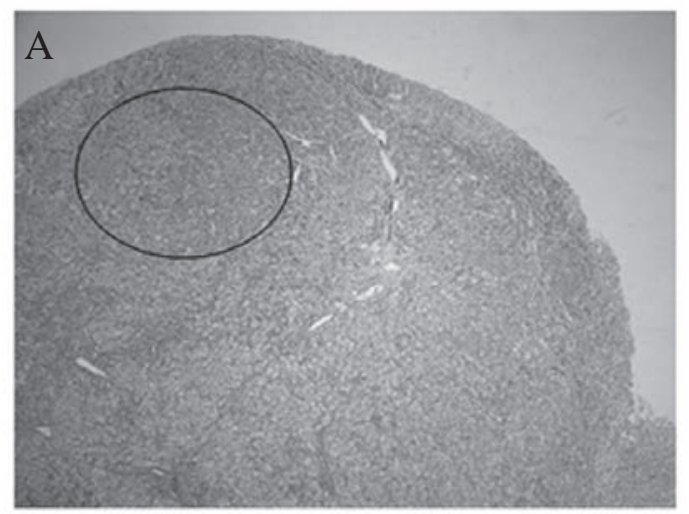

C

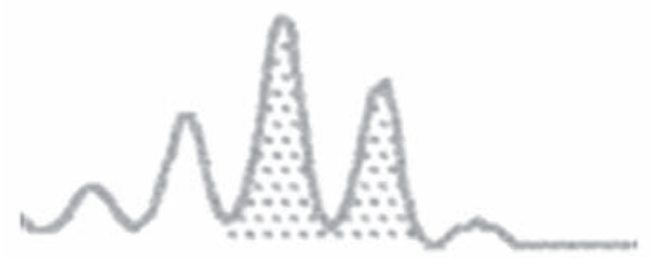

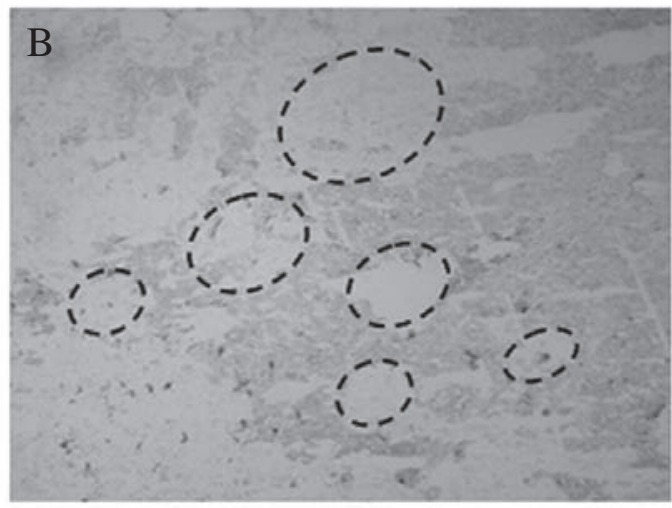

$\mathrm{D}$

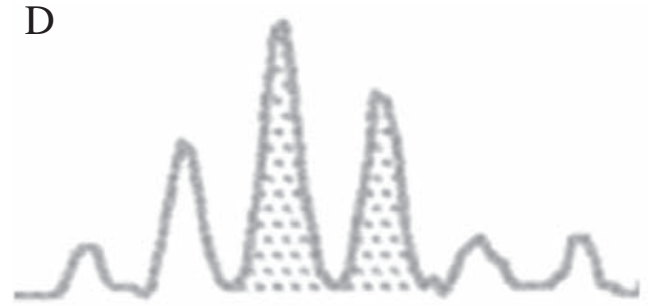

Figure 2. (A) A transverse section of the adrenal gland indicates a PPNAD nodular area (circle), in which laser-captured microdissection was performed. (B) A magnification of the circle area (A) stained with Toluidine blue showing the microdissected areas (dashed outlines). ( $C$ and $D$ ) The dinucleotide repeat (CA)n intragenic marker for PRKARlA gene was in heterozygous state as well as p. Y21X mutation in blood tissue and microdissected nodules, demonstrating that no PRKAR1A LOH was identified in laser-captured PPNAD cells.

\section{DISCUSSION}

Tumour-suppressor genes generally act in a recessive way, requiring loss of both copies to induce tumorigenesis, whereas haploinsufficiency only leads to tumour development predisposition. However, PRKARIA, a potential tumour suppressor gene, has not been consistently associated with $\mathrm{LOH}$ in adrenocortical tumour tissues of patients with Carney complex. This might be ascribed to the fact that the exclusion of potential normal tissue contamination was not performed $(4,12)$.

A recent LOH study using a single polymorphic marker GATA1E12, located $3 \mathrm{cM}$ upstream the PRKA$R I A$ gene, showed LOH occurrence only in microdissected PPNAD tissue, suggesting that the absence of $\mathrm{LOH}$ in previous analyses could occur due to contamination with surrounding cortex (15). In our study, both the p. Y21X mutation and the intragenic marker for PRKARIA were identified in heterozygous state in the laser-captured microdissected cells using two different molecular approaches: automated sequencing and Genescan analysis, respectively. In summary, we de- monstrated that the laser-captured PPNAD cells can preserve the WT PRKARIA allele, indicating that this allele retention is not a consequence of contamination with normal surrounding cortex.

PRKARIA haploinsufficiency has been hypothesized to cause tumours in patients with Carney complex (4). The most likely mechanism by which a truncated $\mathrm{Rl} \alpha$ protein could lead to cAMP signalling alterations is a dominant negative effect on $\mathrm{Rl} \alpha$-mediated inhibition of the PKA catalytic subunit (12). The heterozygous p. Y21X mutation encodes a substitution of a highly conserved tyrosine by a stop codon, predicted to lead to a truncated protein in this young Brazilian male patient with PPNAD. Most of the PRKARIA defects described to date are functionally null heterozygous mutations $(5,12,19)$. Interestingly, two large families that share the 578delTG PRKARIA mutation have different phenotypes, suggesting failure of $P R K A R I A$ genotype-phenotype correlation $(4,20)$. Similarly, a variable clinical expression ranging from subclinical to overt Cushing syndrome was associated with the p. Y21X mutation of 
PRKARIA in the family described here. This phenotypic variability is likely to be a consequence of as-yet-unidentified modifying genetic and/or environmental factors.

Recently, Horvath and cols. (8) identified germline mutations of the phosphodiesterase gene in 3 kindreds with Cushing syndrome and micronodular hyperplasia that were not caused by known defects in other genes. The finding of inactivating mutations of the phosphodiesterase gene in micronodular hyperplasia raises the possibility of yet-unknown abnormalities in signal transduction proteins that interact with $\mathrm{Rl} \alpha$ and cAMP-dependent PKA, and eventually contribute to tumorigenesis in patients whose tumours do not display PRKARIA LOH.

Similarities and dissimilarities between human Carney complex phenotypes and murine Prkarla haploinsufficiency have been observed $(19,21)$. Two hallmarks of Carney complex, spotty pigmentation and cardiac myxomas are not evident in Prkarla $a^{+/}$mice. Absence of cardiac myxomas in prkarla $a^{+/}$mice suggests that Prka$r l a$ haploinsufficiency is insufficient to produce cardiac tumorigenesis. Nevertheless, tumours such as hemangiosarcomas and myxoid fibrosarcomas that arise in Prkarla ${ }^{+/}$mice do not display prkarla LOH (19). As demonstrated in a mouse model for the Carney complex tumour syndrome, we showed that human tumour cells can similarly preserve the WT PRKARIA allele in affected tissues of patients with Carney complex.

In conclusion, we identified a new PRKARIA nonsense mutation (p. Y21X) associated with a variable clinical expression of the PPNAD phenotype. In addition, we demonstrated absence of PRKARIA LOH in laser-captured tumour cells, indicating that adrenocortical tumorigenesis in Carney complex occurs apart from the second hit.

Acknowledgments. We thank the staff of Laboratório de Hormônios e Genética Molecular/LIM 42 for precise technical assistance and Ms. Sonia Strong for the English review. Disclosure Statement: We declare no duality of financial interest or direct or indirect conflict of interest on the part of any author of this manuscript.

\section{REFERENCES}

1. Stratakis CA, Kirschner LS, Carney JA. Clinical and molecular features of the Carney complex: diagnostic criteria and recommendations for patient evaluation. J Clin Endocrinol Metab. 2001;86:4041-6.
2. Horvath A, Stratakis C. Primary pigmented nodular adrenocortical disease and Cushing's syndrome. Arq Bras Endocrinol Metabol. 2007;51:1238-44.

3. Kirschner LS, Carney JA, Pack SD, Taymans SE, Giatzakis C, Cho YS, et al. Mutations of the gene encoding the protein kinase A type I-alpha regulatory subunit in patients with the Carney complex. Nat Genet. 2000;26:89-92.

4. Casey M, Vaughan CJ, He J, Hatcher CJ, Winter JM, Weremowicz S, et al. Mutations in the protein kinase A R1alpha regulatory subunit cause familial cardiac myxomas and Carney complex. J Clin Invest. 2000;106:R31-8.

5. Kirschner LS, Sandrini F, Monbo J, Lin JP, Carney JA, Stratakis CA. Genetic heterogeneity and spectrum of mutations of the PRKAR1A gene in patients with the carney complex. Hum Mol Genet. 2000;9:3037-46.

6. Sandrini F, Stratakis C. Clinical and molecular genetics of primary pigmented nodular adrenocortical disease. Arq Bras Endocrinol Metabol. 2004;48:637-41.

7. Stratakis CA, Carney JA, Lin JP, Papanicolaou DA, Karl M, Kastner $\mathrm{DL}$, et al. Carney complex, a familial multiple neoplasia and lentiginosis syndrome. Analysis of 11 kindreds and linkage to the short arm of chromosome 2. J Clin Invest. 1996;97:699-705.

8. Horvath A, Boikos S, Giatzakis C, Robinson-White A, Groussin $\mathrm{L}, \mathrm{Griffin} \mathrm{KJ}$, et al. A genome-wide scan identifies mutations in the gene encoding phosphodiesterase 11A4 (PDE11A) in individuals with adrenocortical hyperplasia. Nat Genet. 2006;38:794-800.

9. Tsilou ET, Chan CC, Sandrini F, Rubin BI, Shen de F, Carney JA, et al. Eyelid myxoma in Carney complex without PRKAR1A allelic loss. Am J Med Genet A. 2004;130:395-7.

10. Bossis I, Voutetakis A, Matyakhina L, Pack S, Abu-Asab M, Bourdeau I, et al. A pleiomorphic GH pituitary adenoma from a Carney complex patient displays universal allelic loss at the protein kinase $A$ regulatory subunit $1 \mathrm{~A}$ (PRKARIA) locus. $J$ Med Genet. 2004;41:596-600.

11. Groussin L, Jullian E, Perlemoine $K$, Louvel A, Leheup B, Luton JP, et al. Mutations of the PRKAR1A gene in Cushing's syndrome due to sporadic primary pigmented nodular adrenocortical disease. J Clin Endocrinol Metab. 2002;87:4324-9.

12. Groussin L, Kirschner LS, Vincent-Dejean C, Perlemoine K, Jullian E, Delemer B, et al. Molecular analysis of the cyclic AMP-dependent protein kinase $A(P K A)$ regulatory subunit $1 \mathrm{~A}$ (PRKAR1A) gene in patients with Carney complex and primary pigmented nodular adrenocortical disease (PPNAD) reveals novel mutations and clues for pathophysiology: augmented PKA signaling is associated with adrenal tumorigenesis in PPNAD. Am J Hum Genet. 2002;71:1433-42.

13. Parhar IS, Ogawa S, Sakuma Y. Laser-captured single digoxigenin-labeled neurons of gonadotropin-releasing hormone types reveal a novel G protein-coupled receptor (Gpr54) during maturation in cichlid fish. Endocrinology. 2004;145:3613-8.

14. Francis DP, Willson K, Davies LC, Coats AJ, Piepoli M. Quantitative general theory for periodic breathing in chronic heart failure and its clinical implications. Circulation. 2000;102:2214-21.

15. Mavrakis M, Lippincott-Schwartz J, Stratakis CA, Bossis I. Depletion of type IA regulatory subunit (Rlalpha) of protein kinase $A$ (PKA) in mammalian cells and tissues activates mTOR and causes autophagic deficiency. Hum Mol Genet. 2006;15: 2962-71.

16. Shattuck TM, Costa J, Bernstein M, Jensen RT, Chung DC, Arnold A. Mutational analysis of $\mathrm{Smad3}$, a candidate tumor suppressor implicated in TGF-beta and menin pathways, in 
parathyroid adenomas and enteropancreatic endocrine tumors. J Clin Endocrinol Metab. 2002;87:3911-4.

17. Pinto EM, Billerbeck AE, Fragoso MC, Mendonca BB, Latronico AC. Deletion mapping of chromosome 17 in benign and malignant adrenocortical tumors associated with the Arg337His mutation of the p53 tumor suppressor protein. J Clin Endocrinol Metab. 2005;90:2976-81.

18. Rossi R, Tauchmanova L, Luciano A, Di Martino M, Battista C, Del Viscovo $L$, et al. Subclinical Cushing's syndrome in patients with adrenal incidentaloma: clinical and biochemical features. J Clin Endocrinol Metab. 2000;85:1440-8.

19. Veugelers $M$, Wilkes $D$, Burton $K$, McDermott DA, Song $Y$, Goldstein MM, et al. Comparative PRKAR1A genotype-phenotype analyses in humans with Carney complex and prkar1a haploinsufficient mice. Proc Natl Acad Sci USA. 2004;101: 14222-7.

20. Danoff A, Jormark S, Lorber D, Fleischer N. Adrenocortical micronodular dysplasia, cardiac myxomas, lentigines, and spindle cell tumors. Report of a kindred. Arch Intern Med. 1987; $147: 443-8$

21. Kirschner LS, Kusewitt DF, Matyakhina L, Towns WH, 2nd, Carney JA, Westphal $\mathrm{H}$, et al. A mouse model for the Carney complex tumor syndrome develops neoplasia in cyclic AMP-responsive tissues. Cancer Res. 2005;65:4506-14.

\section{Correspondence to:}

Maria Candida Barisson Villares Fragoso

Unidade de Endocrinologia do Desenvolvimento e Laboratório de Hormônios e Genética Molecular LIM-42, Hospital das Clínicas da Faculdade de Medicina da Universidade de São Paulo

Av. Dr. Enéas de Carvalho Aguiar, 155, $2^{\circ}$ andar Bloco 6 05403-900, São Paulo, SP, Brasil

E-mail: mariafragoso@uol.com.br 